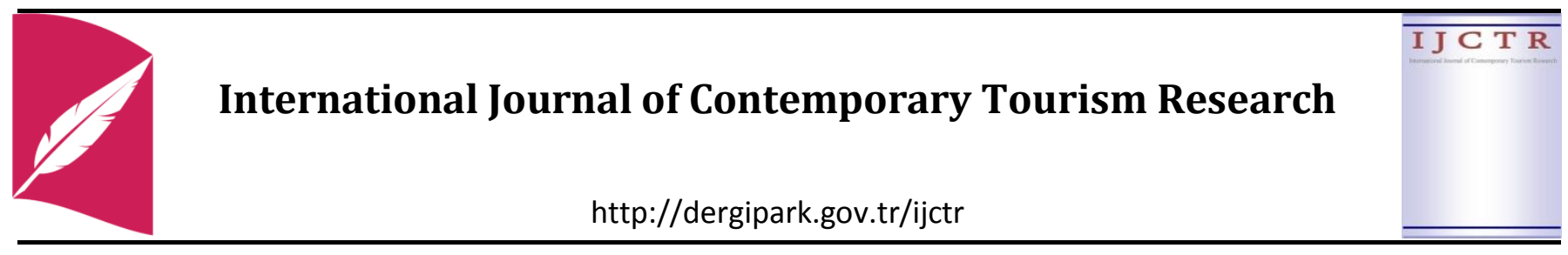

\title{
A RESEARCH ON THE INVESTIGATION OF THE ATTITUDES OF THE LOCAL PEOPLE IN ESKIŞEHIR TOWARDS FAITH TOURISM \\ Research Article
}

Davut UYSAL ${ }^{1}$

\begin{abstract}
Tourism has been gaining more shares in countries' economies. Therefore, countries are looking for alternative ways to diversify their tourism products to have a bigger share from tourism. Eskişehir is a province in Turkey which has been attracting more and more visitors and increasing its income from tourism. This study aims to find out the perceptions of the people in Eskişehir regarding faith tourism considering that residents' perceptions and attitudes are important for a successful promotion of faith tourism in a region. To base the study on a theoretical framework, a comprehensive literature review was conducted on faith tourism. Then the assets of Eskişehir which could have a potential for faith tourism were listed. A questionnaire was adapted and then used to gather the views of the people in Eskişehir regarding faith tourism. It was found that the people in Eskişehir did not perceive faith tourism as a threat in general; rather they perceived it as an opportunity for touristic development in the city.
\end{abstract}

Keywords: Tourism, Faith Tourism, Eskişehir

Jel Classification Codes: L83, G14

\footnotetext{
${ }^{1}$ Ph.D., Anadolu University, School of Foreign Languages, davutu @ anadolu.edu.tr, orcid.org/0000-0001-8241-4407

“Uysal D. (2019). A Research On The Investigation Of The Attitudes Of The Local People In Eskişehir Towards Faith Tourism, International Journal of Contemporary Tourism Research, Vol 3: No: 1, p.28-42, doi: 10.30625/ijctr.545480" 


\section{INTRODUCTION}

Faith tourism is one of the oldest forms of tourism in history. It has been practised by the people travelling from one place to another to visit the holy sites in their religions. The date of such tourism activities can be traced back to the Roman, Greek, Egyptian and Indus Valley civilizations (Jackowski and Smith, 1992, in Rodriques, 2012). As suggested in major holy books, the sites which are holy for some religions have been visited by those admiring them or by the people having similar beliefs at heart. Thus visitors have the chance to learn more about the holy sites and their religion. In today's world, such sites have turned into popular faith tourism centres creating a big economic value in billion dollars in tourism market (Wright, 2007). Thanks to the faith tourism, the income of the host societies has increased, and the economies of the host communities have improved significantly. Considering that those involved in faith tourism is mostly from four major religions, Christians, Muslims, Hindus and Buddhists (Gan et al., 2000) and that they constitute the great majority of world population, it becomes more obvious that faith tourism has a big potential in the tourism market.

This study is a significant one because there is no study in the literature investigating the perceptions and attitudes of local people in Eskişehir for faith tourism whereas Eskişehir has made great progress in tourism and it also aims to increase its share in tourism income in the future. If the local authorities responsible for the development of tourism in Eskişehir are looking for alternative ways to diversify tourism in the city and to extend tourism activities through the year and spread the touristic activities across the province, the findings of this study will have great significance to shed light on such efforts in the future.

\section{LITERATURE REVIEW}

The World Tourism Organization (WTO, 2011) suggests that faith tourism is closely related to the beliefs that have been transferred from generation to generation, and it is a good way of learning about people's backgrounds and cultures in different areas. The cultural values of the societies are presented to visitors through tourism-related activities (Vidic, 2007). Moreover, believers of some religions may be required to worship for a period of time, (Angeles \& Javier, 2008). There are many studies in the literature suggesting various definitions for faith tourism. Egresi et al. (2012) define faith tourism as all travels to the sites with religious importance for believers. Vorzsak and Gut (2009) suggest another definition; faith tourism means visiting sites, shrines and structures with religious importance as well as attending religious conferences, experiencing different culturally religious events, exhibitions of cultic object and concerts of sacred music. It is also defined as the visits of people from different religions to sacred places as well as all travels for the purpose of satisfying visitors' beliefs (Tunç and Saç, 1998: 24)

\section{The Relationship between Tourism and Belief}

Faith tourism is a term which is in general used to refer to the visits for religious purposes. With this regards, faith tourism is a field of activity where religion and tourism terms interact with one another (Timothy and Olsen, 2006:8). As they have been interacting with one another, one of them cannot be considered without the other, and there is a need for the clarification of the term of faith tourism. Religion is "a conceptual system that provides an interpretation of the world and the place of human beings in it, bases an account of how life should be lived given that interpretation and expresses this interpretation and lifestyle in a set of rituals, institutions, and practices" (Yandell 1999). All religions have a system of values to some extent and they have universal belief systems. The system of belief is considered to be the most basic need of human being and therefore it significantly shapes human behaviours. The power of beliefs on human behaviours also functions as a source of motivation leading individuals to some behaviour. Faith tourism is a field of tourism considered with this regard. Human being aims to have a sense of psychological satisfaction through religion-based visits. As people tend to need more psychological satisfaction, the number of people participating in religion based tourism increases. As religion has always been an important factor in human life, the religion based visits, which are named as faith tourism has also become an important source of income for the tourism sector. Those who participate in faith tourism consider religion very important in their lives and the people of the region where faith tourism activities are fulfilled consider 
religion very important for both their benefits and for those visiting their regions as part of faith tourism activity. For faith tourism to effectively function there should be a match between those participating in faith tourism and those hosting the visitors in their regions. Showing respect to the beliefs of visitors and empathizing visitors are closely related to the effective functioning of faith tourism in a region (Karaman and Usta, 2006:473).

The economic contribution of religion has always attracted the establishments operating in the tourism sector because believers are always ready to spend more for their beliefs, which is a basic motivation for the establishments in tourism to be interested in faith tourism (Karaman and Usta, 2006: 473, 474). The economy-related effects of faith tourism result in many consequences in international relations among countries (Akat, 2000:24). Almost all religions have encouraged their believers to travel for religious purposes, and they created religion based activities leading to economic growth. The increase in wealth in the holy cities of middle ages was a consequence of religion-based travels in the world. What makes faith tourism different from other types of tourism is that it is beyond individual preferences but a necessity of the religion that they believe in. All religion based travels are not equally important for believers. It was mostly dependent on the purpose of the religious travel and its content rather than the importance of the destination, region and building for the religion. The places and buildings visited within the scope of religion are unique to some religions and they are not open to the visits of the believers of other religion. For example, Islam religion has some places which are closed to the visits of the believers of other religions. This may seem to be a barrier to the increase in the number of people visiting those places, but it is not so actually. As such places are considered to have more significance for their religion; almost all believers of that religion tend to visit these places.

Holy sites are the centres of communities, and they tend to guide human life and also make human life meaningful. No matter what religion individuals are from, the human being needs to visit holy places temperamentally. What human beings feel at holy sites is different from what they feel in any other place. Because holy sites are the places where God and people are considered to meet and people feel more secure (Erbaş, 2002: 98). The travels carried out for religious purposes make it compulsory for travellers to see different cities and spend time and money there for a while, which economically, socially and culturally affect the visited places. The local economy grows, employment rates increase and local people have the chance to interact with other cultures. The destination gains more popularity and attracts more visitors in time.

\section{Importance of Faith Tourism}

The importance of any tourism branch in the sector is closely related to the total number of tourists and the size of the market it targets (Hacioğlu, 2000). When the number of believers is considered from all religions in the world, it is easy to predict the potential size of the market that faith tourism has. Believers' participation in religion-based travels as their belief requires, increases the number of visitors to the holy places in their religions. Rojo (2007) claims that about 300 million people travel in the world from different religions for religious purposes. The size of the market that these people forms is about 18 billion dollars a year (Wright, 2007: 1). The estimate suggested by WTO for faith tourism in the future is that faith tourism will have grown by $20 \%$ until 2020 (McKelvie, 2005). In addition to the economic contribution of faith tourism mentioned above, faith tourism also encourages interaction among different cultures as some faith tourism destinations host places holy for more than one religion. Jerusalem is a good example of that as it is an important faith tourism destination for three divine religions, Islam, Judaism and Christianity. When religion has worldwide believers throughout the world, that religion is considered to have a big economic potential in faith tourism. With this regard, Islam, Christianity and Hinduism are considered to have the biggest potentials for the faith tourism market in the world when the number of believers is considered in these three religions.

\section{Major Reasons for Participation in Faith Tourism}

In major religions, the reason for believers to participate in faith tourism is to accomplish at least one of the following targets (Usta, 2005:8-9).

- To make a pilgrimage as part of religious necessity: Pilgrimage is a way of moral catharsis, salvation and praying in many 
religions. In Islam and Judaism, it is compulsory to make a pilgrimage to holy places for their religions.

- To fulfil a vow taken before, express gratitude to their God, sanctify and make a wish: when believers face a problem which they cannot overcome by their own in life, they look for divine help to solve it. The aim of a visit to a holy place is to find the divine help looked for. Believers confess their sins there take a vow, repent and promise that they will lead a religious life in their future lives.

- To reach a superior position socially and morally: when socially considered, travelling for religious purposes is a signal of piety which is considered to be a merit in the society

- To celebrate and commemorate some religious events; every religion has some unique ceremonies and rituals which are considered to be blessed for their believers. Birthday of their prophets, death anniversary of holy people, the journeys that holy people had in the past is recorded in religious doctrine and legends. They are repeated by believers in religious festivals to remember them.

- To interact and connect with those believing in the same religion: missionary meetings and pilgrimages can be given a good example of this. The rationale behind the pilgrimages in many religions is to gather the believers of the same religion.

- To spread the truth: Many religions support missionary activities for the purpose of spreading religion and teaching people the truth.

- To organize conferences and religious meetings; Religious groups also need to carry out their activities effectively as non-religious groups do. Therefore, religious groups organize periodical meetings in which they can monitor their progress and those of their members.

\section{Faith Tourism in Turkey}

As Anatolia, which has been home to Turks for hundreds of years is full of traditions, customs, architectural works from different eras, it is a rich source of income for modern tourism. Besides, Anatolia has been a centre for three divine religions, Islam, Christianity and Judaism (Kozak et.al., 2010). The Ministry of Culture and Tourism in Turkey conducted a comprehensive study in
1993 to take the inventory of the places which have significance for three divine religions. The findings of this study suggested that Anatolia hosts 316 holy places which are important for the three divine religions (Zengin, 2010). 1995 was the year when religion-based touristic activities started with the help of many tour operators. Moreover, the issue of faith tourism has become an interest of the public in Turkey with the help of similar studies conducted by local governors and universities (Sargin, 2006). The Ministry of Culture and Tourism has started to give priority to the physical improvements and introduction of the faith centres which have the potential to be popular faith tourism destinations.

\section{ESKIŞEHIR, THE FOCUS OF THE STUDY}

Eskişehir is a province 315 kilometre to İstanbul and 240 to Ankara, which is the capital city of Turkey. Eskişehir is known to be the city having a geographical advantage of being the door to West Anatolia. Eskişehir has become an economic centre because it is located at an intersection point where railways and motorways meet. It is also a commercial and industrial centre with its rich underground treasures. Eskişehir is a city with a rich educated human resource. $99 \%$ of the people living in the province are literate. It hosts three state universities in the city centre. With the help of the commercial and industrial improvements, socio-economic life has been improving very quickly. It ranks at the $7^{\text {th }}$ position with regards to developmental level. According to the report released by CNBC-e, Eskişehir is the $3^{\text {rd }}$ city of Turkey with regards to developmental level. Urbanization rate of the city is $88 \%$, and per capita income in the city is about 14.000 US Dollar, which is well above the average of the country (EOSB 2019). With the recent projects which have been brought into action in Eskişehir province, it has become a city which has made a name at national and international level. The number of people visiting the city has increased since 2001 . For example, the number of hotels with tourism establishment certificates increased by $435 \%$ from 2001 to 2017. Similarly, the number of visitors overnighting at the hotels in the city increased by $820 \%$ from 2001 to 2017 (EBB 2019). 
The Assets Which Could Have Potential for Faith Tourism in Eskişehir Province

The assets which could have a value for the faith tourism in Eskişehir are old mosques, masjids, tombs and domes and some old churches. The mosques and tombs are mostly suggested to be significant attractions for domestic tourism, but churches are considered to be important touristic assets for foreign travellers as well as domestic travellers. Major Mosques and Masjids which could be subject to faith tourism in Eskişehir are Kurşunlu Mosque, Reşadiye Mosque, Alaaddin Mosque, Sivrihisar Ulu Mosque, Kurşunlu Mosque, Hoşkadem Camii, Hazinedar Mescidi, Balaban Mosque, Hamamkarahisar Mosque, Aziz Mahmud Hüdai Mosque, Hızır Bey Mesjid, Akdoğan Mosque, Kılıç (Sword) Minaret, Elmalı Mosque, Çalçı Village Mosque, Mihalıççık Ulu Mosque, Hüsrev Paşa Mosque. There are also some churches which could be subject to faith tourism in Eskişehir Province; which are Old Church (Asri Sinema), Armenian Church and Gökçeyayla Church. The tombs and domes which could be subject to faith tourism in Eskişehir province are Şeyh Ahi Mahmut Tomb, Şeyh Edebali Tomb, Şeyh Şehabeddin Sühreverdi Tomb, Seyyid Battal Gazi Tomb, Ümmühan Hatun Tomb, Üryan Baba Tomb, Melik Gazi Tomb, Sücaeddin Veli Baba Tomb, Himmet Baba Dome, Elveren Tomb, Hoca Yunus Tomb, Alemşah Dome, Mahmud Suzani Tomb and Yunus Emre Tomb (Şahin, 2012))

\section{Purpose of the Study}

Faith tourism has been gaining popularity in the tourism sector in recent years in Turkey in parallel with the world. Eskişehir, where this study was conducted has a significant number of sites with potential for faith tourism. Eskişehir is located at a geographically advantaged position in Turkey in terms of transportation facilities. However, Eskişehir cannot benefit from its existing potential adequately (Seçilmiş, 2011) whereas it has already made significant progress in mass tourism in the last decade.

The development of tourism is closely related to the perceptions and attitudes of the local people. When local people have positive attitudes and perceptions towards faith tourism, it becomes easier to develop this tourism type in that region. If local people have negative perceptions and attitudes towards faith tourism, they will be resistant to the development of faith tourism in the region (Jennings, 2001). Therefore, the purpose of this study is to reveal the perceptions and attitudes of local people living in the city centre of Eskişehir. For this purpose, this study aims to test the following hypotheses;

H1: People in Eskişehir perceive faith tourism as a threat.

H1a: There is no relationship between gender and the level of threat felt for faith tourism.

H1b: There is no relationship between age and the level of threat felt for faith tourism.

H1c: There is no relationship between marital status and the level of threat felt for faith tourism.

HId: There is no relationship between educational level and the level of threat felt for faith tourism.

Hle: There is no relationship between political view and the level of threat felt for faith tourism.

$\mathrm{H} 2$ : People in Eskişehir consider faith tourism as an opportunity.

H2a: There is no relationship between gender and the positive contribution of faith tourism.

$H 2 b$ : There is no relationship between age and the positive contribution of faith tourism.

H2c: There is no relationship between marital status and the positive contribution of faith tourism.

H2d: There is no relationship between education level and the positive contribution of faith tourism.

H2e: There is no relationship between political view and the positive contribution of faith tourism.

\section{METHODOLOGY}

This study was conducted at two stages. In the first stage of the study, a detailed literature review regarding faith tourism was conducted. In the second stage of the study, a questionnaire was adapted from Şahiner (2012). The original questionnaire was in the Turkish language, and only the items measuring the perceptions and attitudes of local people were adopted for Eskişehir context where this research was conducted. The adapted questionnaire which was also in the 
Turkish language as the original questionnaire was used to gather data. The questionnaire was designed to collect the general opinions of the local people regarding faith tourism in Eskişehir. The probabilistic sampling method was used in the study to give every individual in Eskişehir the chance to have equal opportunity to be a participant of the study. To achieve that, random sampling was done in data collection. The 2017 population of Eskişehir city centre was taken into consideration in the determination of the sampling. The number of target individuals in the city centre was (N) 763,570 (Nufusu.com 2019). The size of the sampling was found out as minimum $n=384$ at a 95\% confidence interval (Cohen, Manion and Morrison, 2000). The adapted questionnaire consists of two parts as part I with the items regarding demographic information of the participants and part II with the items measuring participants' attitudes towards faith tourism. Participants were requested to choose the right option out of "I strongly disagree, I disagree, neutral, I agree and I strongly agree". The questionnaire was administered between April and June 2018 by the researcher. All participants were asked how long they had been living in Eskişehir before delivering the questionnaire. If they were found to have been living in Eskişehir, the questionnaire was given to the respondents. Those who responded that they were not living in Eskişehir, but visiting the city for a short while were not given the questionnaire.

\section{Data Analysis}

The responses of the participants to the items in the questionnaire were coded and transferred to a statistical program. Frequency and percentage distribution tests, means and standard deviations analysis, factor analysis, one sample t-test, independent samples t-test and one-way ANOVA test were administered to the coded data.

\section{FINDINGS}

\section{General Information about the participants}

120 of the participants $(32,7 \%)$ were male and 264 of them $(67,3 \%)$ were female. When the participants' age ranges were considered, it was seen that 114 of the participants $(29,1 \%)$ were between the ages of $15-24,95$ of them $(24,2 \%)$ were between $25-34,108$ of them $(27,6 \%)$ were between $35-44,61$ of them $(15,6 \%)$ were between $45-54$ and 61 of them $(15,6 \%)$ were 55 and above.
237 of the participants $(60,7 \%)$ were married and 155 of them $(39,5 \%)$ were single. When the participants' average monthly income was considered, 34 of them $(8,7 \%)$ were found to have 2000 TL and below, 72 of them $(18,4)$ had an average income between 2001 and 4000 TL, 119 of them $(30,4)$ had an average income between 4001 and $6000 \mathrm{TL}, 76$ of them $(19,4 \%)$ had an average income between 6001 and 8000 TL, 58 of them $(14,8 \%)$ had an average income between 8001 and $10.000 \mathrm{TL}$, and 33 of them $(8,4 \%)$ stated that they had an average monthly income of 10001 and above (see Table 1).

Table 1. Demographic information about the participants

\begin{tabular}{|c|c|c|c|}
\hline & & $\mathbf{F}$ & $\%$ \\
\hline \multirow{2}{*}{ Gender } & Male & 128 & 32,7 \\
\hline & Female & 264 & 67,3 \\
\hline \multirow{5}{*}{ Age } & $15-24$ & 114 & 29,1 \\
\hline & $25-34$ & 95 & 24,2 \\
\hline & $35-44$ & 108 & 27,6 \\
\hline & $45-54$ & 61 & 15,6 \\
\hline & 55 and above & 14 & 3,6 \\
\hline \multirow{2}{*}{$\begin{array}{l}\text { Marital } \\
\text { Status }\end{array}$} & Married & 237 & 60,5 \\
\hline & Single & 155 & 39,5 \\
\hline \multirow{7}{*}{$\begin{array}{l}\text { Average } \\
\text { Income }\end{array}$} & Below $2000 \mathrm{TL}$ & 34 & 8,7 \\
\hline & $2001-4000 \mathrm{TL}$ & 72 & 18,4 \\
\hline & 4001-6000 TL & 119 & 30,4 \\
\hline & 6001-8000 TL & 76 & 19,4 \\
\hline & $8001-10.000 \mathrm{TL}$ & 58 & 14,8 \\
\hline & Above $10001 \mathrm{TL}$ & 33 & 8,4 \\
\hline & Total & 392 & 100,0 \\
\hline
\end{tabular}

As seen in Table 2, 121 of the participants $(30,9 \%)$ had been abroad for a touristic visit, and 271 of them $(69,1)$ had not been abroad before for any purpose. 325 of the participants $(82,9 \%)$ had domestic touristic experience before and 67 of them $(17,1 \%)$ of them did not have any domestic travel for touristic purposes. 247 of them $(63,3 \%)$ were found to have a faith tourism activity before, and 145 of them (37\%) did not have any faith tourism activity before. 115 of the participants $(29,3 \%)$ were found to be from Eskişehir, 136 of them $(34,7 \%)$ had been living in Eskişehir between 1 and 5 years, 54 of them $(13,8 \%)$ had been living in Eskişehir between 6 and 10 years, and 87 of them $(22,2 \%)$ had been living in Eskişehir for more than 10 years. 
Table 2. Demographic information about the participants

\begin{tabular}{|c|c|c|c|}
\hline \multirow{3}{*}{\begin{tabular}{|l|} 
Been abroad \\
before
\end{tabular}} & & $\mathbf{F}$ & $\%$ \\
\hline & Yes & 121 & 30,9 \\
\hline & No & 271 & 69,1 \\
\hline \multirow{2}{*}{$\begin{array}{l}\text { Any domestic } \\
\text { touristic visit } \\
\text { before }\end{array}$} & Yes & 325 & 82,9 \\
\hline & No & 67 & 17,1 \\
\hline \multirow{2}{*}{$\begin{array}{l}\text { Any faith } \\
\text { tourism } \\
\text { Activity } \\
\text { before } \\
\end{array}$} & Yes & 247 & 63,0 \\
\hline & No & 145 & 37,0 \\
\hline \multirow{5}{*}{$\begin{array}{l}\text { Duration of } \\
\text { living in } \\
\text { Eskişehir }\end{array}$} & I'm from Eskişehir & 115 & 29,3 \\
\hline & $\begin{array}{l}\text { Been in Eskişehir } \\
\text { between 1-5 years }\end{array}$ & 136 & 34,7 \\
\hline & $\begin{array}{l}\text { Been in Eskişehir } \\
\text { between 6-10 years }\end{array}$ & 54 & 13,8 \\
\hline & $\begin{array}{l}\text { Been in Eskişehir for } \\
\text { more than } 10 \text { years }\end{array}$ & 87 & 22,2 \\
\hline & Total & \multicolumn{2}{|c|}{\begin{tabular}{l|l}
392 & 100,0 \\
\end{tabular}} \\
\hline
\end{tabular}

As seen in Table 3, 22 of the participants $(5,6 \%)$ were graduates of primary school, 160 of them $(40,8 \%)$ were graduates of either secondary or high school, 190 of them $(48,5 \%)$ were graduates of university, and 20 of them $(5,1 \%)$ had a postgraduate degree.

Table 3. Participants' levels of education

\begin{tabular}{|l|r|r|}
\hline & \multicolumn{1}{|c|}{ F } & \multicolumn{1}{c|}{$\%$} \\
\hline Primary School & 22 & 5,6 \\
\hline Secondary/high school & 160 & 40,8 \\
\hline University & 190 & 48,5 \\
\hline Postgraduate & 20 & 5,1 \\
\hline Total & $\mathbf{3 9 2}$ & $\mathbf{1 0 0 , 0}$ \\
\hline
\end{tabular}

As seen in Table 4, the distribution of participants by occupations are as follows; 3 of them $(8,4 \%)$ were students, 14 of them $(3,6 \%)$ were farmer, 75 of them $(19,1 \%)$ were retired.

Table 4. Occupations of the participants

\begin{tabular}{|l|r|r|}
\hline & F & \multicolumn{1}{|c|}{$\%$} \\
\hline Student & 33 & 8,4 \\
\hline Farmer & 14 & 3,6 \\
\hline Retired & 75 & 19,1 \\
\hline Civil servants & 101 & 25,8 \\
\hline Artisan & 52 & 13,3 \\
\hline Housewife & 24 & 6,1 \\
\hline Independent Business & 46 & 11,7 \\
\hline Unemployed & 18 & 4,6 \\
\hline Merchant & 16 & 4,1 \\
\hline Industrialist & 13 & 3,3 \\
\hline Total & $\mathbf{3 9 2}$ & $\mathbf{1 0 0 , 0}$ \\
\hline
\end{tabular}

101 of them $(25,8 \%)$ were civil servants, 52 of them $(13,3 \%)$ were artisan, 24 of them $(6,1 \%)$ were housewife, 46 of them $(11,7 \%)$ were independent business, 18 of them $(4,6 \%)$ were unemployed, 16 of them $(4,1 \%)$ were merchant and 13 of them $(3,3 \%)$ were industrialist.

When the participants' political views were considered as seen in Table 5, it was found that 40 of them $(10,2 \%)$ defined themselves as religionist/conservative, 85 of them $(21,7 \%)$ as nationalist/conservative, 87 of them $(22,2 \%)$ as social democrat, 14 of them $(3,6 \%)$ as liberal democrat and 135 of them $(34,4 \%)$ as other.

Table 5. Political views of the participants

\begin{tabular}{|l|r|r|}
\hline \multicolumn{1}{c|}{} & \multicolumn{1}{|c|}{ F } & \multicolumn{1}{c|}{ \% } \\
\hline Religionist/conservative & 40 & 10,2 \\
\hline Nationalist/conservative & 85 & 21,7 \\
\hline Social democrat & 87 & 22,2 \\
\hline Socialist & 31 & 7,9 \\
\hline Liberal Democrat & 14 & 3,6 \\
\hline Other & 135 & 34,4 \\
\hline Total & $\mathbf{3 9 2}$ & $\mathbf{1 0 0 , 0}$ \\
\hline
\end{tabular}

\section{Findings Regarding the Opinions of the people} in Eskișehir about Faith Tourism

The questionnaire used to collect the views of the people in Eskişehir was adapted from Şahiner (2012); therefore, a confirmatory factor analysis (Principle Component Analysis) was conducted on the data in the study. The principle Component Analysis results are seen in Table 6. According to the factor analysis, questionnaire items were found to go under two factors, which are "threat" and "opportunity". The Cronbach Alpha reliability of the "threat" factor was found to be (Cronbach $\alpha=$ 0,726), and Cronbach Alpha reliability of the "opportunity" factor was found to be (Cronbach $\alpha=$ 0,834). Cronbach's alpha is described as 'one of the most important and pervasive statistics in research involving test construction and use' (Cortina, 1993, p. 98) to the extent that its use in research with multiple-item measurements is considered routine (Schmitt, 1996, p.350). 
Table 6. Principal component analysis of the items

\begin{tabular}{|c|c|c|c|}
\hline \multirow{2}{*}{ Confirmatory Factor Analysis } & 1 & 2 & \multirow{2}{*}{ Excluded } \\
\hline & Threat & Opportunity & \\
\hline Missionary activities are carried out under the name of faith tourism & 690 & & \\
\hline $\begin{array}{l}\text { As faith tourism develops, it will increase the interest of the people of } \\
\text { Eskisehir in other beliefs. }\end{array}$ & ,628 & & \\
\hline The restoration of historical sites belonging to Christians worries me & 650 & & \\
\hline $\begin{array}{l}\text { As faith tourism develops, the behaviours of the people in Eskişehir will } \\
\text { change. }\end{array}$ & 635 & & \\
\hline Faith tourism will change the entertainment culture in Eskişehir & 685 & & \\
\hline $\begin{array}{l}\text { The restoration of the Greek and Armenian historical monuments will lead to } \\
\text { foreigners' claims }\end{array}$ & ,699 & & \\
\hline $\begin{array}{l}\text { I think that touristic mobility has an effect on the provision of world peace } \\
\text { and countries' getting closer to one another }\end{array}$ & & 775 & \\
\hline $\begin{array}{l}\text { Development of faith tourism in Eskişehir will contribute to the beliefs' } \\
\text { getting closer to one another }\end{array}$ & & ,716 & \\
\hline $\begin{array}{l}\text { Programs should be organized in order to raise public awareness of faith } \\
\text { tourism. }\end{array}$ & & ,777 & \\
\hline $\begin{array}{l}\text { I would like to welcome foreign authorities' (Papacy, UNESCO) } \\
\text { contributions to the restoration of historical remains in Eskişehir }\end{array}$ & & 656 & \\
\hline Faith tourism will contribute to the development of Eskisehir's faith culture. & & ,751 & \\
\hline $\begin{array}{l}\text { I am positive for the restoration of the old churches and opening them for } \\
\text { touristic purposes }\end{array}$ & & & , 480 \\
\hline I am positive for uncovering the historical ruins with faith tourism value & & & ,374 \\
\hline $\begin{array}{l}\text { Development of faith tourism in Eskişehir will cause local people to be } \\
\text { affected frım their cultural values }\end{array}$ & & & ,426 \\
\hline $\begin{array}{l}\text { The mosques in Eskişehir province are important for the city's faith tourism } \\
\text { potential }\end{array}$ & & & ,395 \\
\hline $\begin{array}{l}\text { The faith tourism sites in Eskişehir are not known adequately both in our } \\
\text { country and in the world }\end{array}$ & & & ,316 \\
\hline $\begin{array}{l}\text { More effort should be spent to raise local peoples' awareness regarding faith } \\
\text { tourism }\end{array}$ & & & ,417 \\
\hline Historical sites are our joint inheritances & & & ,450 \\
\hline
\end{tabular}

Note: ,5 and above was considered practically significant (Hair et.al., 1998, pg. 111)

\section{TESTING HYPOTHESIS}

\section{H1: People in Eskişehir perceive faith tourism as a threat.}

As seen in Table 7, the One Sample T-test conducted on the data to see if the people in Eskişehir perceived faith tourism as a threat or not revealed that the average score significantly differed from the test value, $3(\mathrm{p}>, 001)$, and participants did not perceive faith tourism as a threat. Therefore, the H1 suggesting that the people in Eskişehir perceive faith tourism as a threat was refused.

Table 7. One sample t-test

\begin{tabular}{|c|c|c|c|c|c|}
\hline & $\mathbf{N}$ & Mean & SD & $\mathbf{t}$ & $\mathbf{p}$ \\
\hline Threat & 392 & 2,6901 &, 90683 & $-6,767$ &, 001 \\
\hline
\end{tabular}

Variance analysis was also conducted on the data to see if the findings of One Sample t-test differed depending on various demographic details about the participants.

\section{H1a: There is no relationship between gender and the level of threat felt for faith tourism.}

As seen in Table 8, no significant difference was found between participants' gender and their levels of threat felt for faith tourism ( $p>, 123)$. Therefore, it could be suggested that the level of threat felt by both men and women in Eskişehir are equal. In line with this finding, it could be suggested that H1a is accepted. 
Table 8. Independent sample t-test between gender and the level of the threat felt faith tourism

\begin{tabular}{|l|l|l|l|l|l|}
\hline & Gender & $\mathbf{N}$ & Mean & SD & p \\
\hline \multirow{2}{*}{ Threat } & Male & 128 & 2,5885 &, 70925 &, 123 \\
\cline { 2 - 6 } & Female & 264 & 2,7393 &, 98601 & \\
\hline
\end{tabular}

H1b: There is no relationship between age and the level of threat felt for faith tourism

One Way ANOVA test was conducted to see if there is a significant relationship between the threat felt for faith tourism and age. As seen in Table 9, it was found that there was a significant relationship between the age and the level of threat felt for faith tourism in Eskişehir $(\mathrm{p}>, 011)$. Therefore, H1b is refused.

Table 9. One-way ANOVA test between the age and level of threat felt for faith tourism

\begin{tabular}{|l|l|l|l|l|}
\hline & Age & N & Mean & p \\
\hline \multirow{4}{*}{ Threat } & $15-24$ & 114 & 2,5921 & 011 \\
\cline { 2 - 4 } & $25-34$ & 95 & 2,8228 & \\
\cline { 2 - 4 } & $35-44$ & 108 & 2,5108 & \\
\cline { 2 - 4 } & $45-54$ & 61 & 2,9508 & \\
\cline { 2 - 4 } & 55 and above & 14 & 2,8333 & \\
\cline { 2 - 4 } & Total & 392 & 2,6901 & \\
\hline
\end{tabular}

As a significant difference was found, the Tukey Post Hoc Test was conducted to see which age groups differed from one another.

Table 10. Tukey post-hoc test

\begin{tabular}{|c|c|c|c|}
\hline Age & & \begin{tabular}{|l} 
Mean \\
Difference
\end{tabular} & $\mathbf{P}$ \\
\hline \multirow[t]{4}{*}{$15-24$} & $25-34$ &,- 23070 &, 345 \\
\hline & $35-44$ &, 08130 & ,962 \\
\hline & $45-54$ &,- 35871 &, 088 \\
\hline & 55 and above &,- 24123 &, 877 \\
\hline \multirow[t]{4}{*}{$25-34$} & $15-24$ &, 23070 &, 345 \\
\hline & $35-44$ &, 31200 &, 098 \\
\hline & $45-54$ &,- 12801 &, 908 \\
\hline & 55 and above &,- 01053 & 1,000 \\
\hline \multirow[t]{4}{*}{$35-44$} & $15-24$ &,- 08130 & ,962 \\
\hline & $25-34$ &,- 31200 &, 098 \\
\hline & $45-54$ &,$- 44002^{*}$ &, 020 \\
\hline & 55 and above &,- 32253 &, 712 \\
\hline \multirow[t]{4}{*}{$45-54$} & $15-24$ &, 35871 &, 088 \\
\hline & $25-34$ &, 12801 & ,908 \\
\hline & $35-44$ &, $44002^{*}$ &, 020 \\
\hline & 55 and above &, 11749 &, 992 \\
\hline \multirow[t]{4}{*}{55 and above } & $15-24$ &, 24123 &, 877 \\
\hline & $25-34$ &, 01053 & 1,000 \\
\hline & $35-44$ &, 32253 &, 712 \\
\hline & $45-54$ &,- 11749 &, 992 \\
\hline
\end{tabular}

As seen in Table 10, it was found that there was a significant difference between those aged between 35-44 and 45-54. In line with this finding that it could be suggested that those aged between 45-54 had a higher level of threat felt for the faith tourism.

H1c: There is no relationship between marital status and the level of threat felt for faith tourism

As seen in Table 11, no significant difference was found between marital status and the level of threat felt for faith tourism in Eskişehir $(p>, 076)$. In line with this finding, it could be suggested that both married and single people do not feel any threat to faith tourism in Eskişehir. Therefore, $\mathrm{H} 1 \mathrm{c}$ hypothesis was accepted.

Table 11. Independent samples t-test between the threat felt for faith tourism marital status.

\begin{tabular}{|l|l|l|l|l|l|}
\hline & Marital Status & N & Mean & SD & P \\
\hline \multirow{2}{*}{ Threat } & Married & 237 & 2,7560 & 1,01129 &, 076 \\
\cline { 2 - 6 } & Single & 155 & 2,5892 &, 70972 & \\
\hline
\end{tabular}

H1d: There is no relationship between educational level and the level of threat felt for faith tourism

As seen in Table 12, the One Way ANOVA test conducted to see if there was any significant difference between the level of threat felt for faith tourism and education level, it was found that there was a significant difference $(\mathrm{p}>, 008)$. Therefore, H1d was refused.

Table 12. One-way ANOVA test between education level and the level of threat felt for faith tourism

\begin{tabular}{|l|l|l|l|l|l|}
\hline & Educational Status & N & Mean & Sd & P \\
\hline \multirow{5}{*}{ Threat } & Primary School & 22 & 3,1212 &, 57777 &, 008 \\
\cline { 2 - 5 } & $\begin{array}{l}\text { Secondary/high } \\
\text { school }\end{array}$ & 160 & 2,7781 &, 72485 & \\
\cline { 2 - 5 } & University & 190 & 2,6061 & 1,04611 & \\
\cline { 2 - 5 } & Postgraduate & 20 & 2,3083 &, 87572 & \\
\cline { 2 - 5 } & Total & 392 & 2,6901 &, 90683 & \\
\hline
\end{tabular}

As seen in Table 13, Tukey Post Hoc Test was conducted to see if there was a significant difference between education levels and the level of threat felt for faith tourism to see which education levels differed from one another. It was found that there was a significant difference between those with a primary school degree and those with a post-graduate degree $(p>, 019)$. It 
could be suggested that primary school graduates had a higher level of threat felt for faith tourism in Eskişehir. As education level increases, the level of threat felt decreases.

Table 13. Tukey post-hoc test between education level and the level of threat felt for faith tourism

\begin{tabular}{|l|l|r|c|}
\hline $\begin{array}{c}\text { Educational } \\
\text { Status }\end{array}$ & \multicolumn{1}{|c|}{$\begin{array}{c}\text { Educational } \\
\text { Status }\end{array}$} & $\begin{array}{c}\text { Mean } \\
\text { Difference }\end{array}$ & P \\
\hline \multirow{4}{*}{ Primary School } & $\begin{array}{l}\text { Secondary/high } \\
\text { school }\end{array}$ &, 34309 &, 334 \\
\cline { 2 - 5 } & University &, 51507 &, 054 \\
\cline { 2 - 5 } Post graduate &, 81288 &, 019 \\
\hline \multirow{2}{*}{$\begin{array}{l}\text { Secondary/high } \\
\text { school }\end{array}$} & Primary School &,- 34309 &, 334 \\
\cline { 2 - 5 } & University &, 17198 &, 281 \\
\cline { 2 - 5 } University & Post graduate &, 46979 &, 123 \\
\hline \multirow{4}{*}{ Post graduate } & Primary School &,- 51507 &, 054 \\
\cline { 2 - 5 } & $\begin{array}{l}\text { Secondary/high } \\
\text { school }\end{array}$ &,- 17198 &, 281 \\
\cline { 2 - 5 } & Post graduate &, 29781 &, 492 \\
\cline { 2 - 5 } & Secondary/high &,- 81288 &, 019 \\
school &,- 46979 &, 123 \\
\cline { 2 - 5 } & University &,- 29781 &, 492 \\
\hline
\end{tabular}

H1e: There is no relationship between political view and the level of threat felt for faith tourism

As seen in Table 14, there was a significant difference between the political views of the participants and the level of threat felt for faith tourism ( $p>, 001)$. Therefore, H1e was refused.

Table 14. One-way ANOVA test between political views and the threat felt for faith tourism

\begin{tabular}{|l|l|r|c|c|c|}
\hline & & N & Mean & SD & p \\
\hline \multirow{5}{*}{ Threat } & $\begin{array}{l}\text { Religionist/ } \\
\text { conservative }\end{array}$ & 40 & 2,8542 &, 58858 &, 000 \\
\cline { 2 - 6 } & $\begin{array}{l}\text { Nationalist/ } \\
\text { conservative }\end{array}$ & 85 & 3,0882 & 1,26554 & \\
\cline { 2 - 6 } & $\begin{array}{l}\text { Social democrat } \\
\text { Socialist }\end{array}$ & 87 & 2,4693 &, 76778 & \\
\cline { 2 - 7 } & Socialist & 2,3280 &, 87611 & \\
\cline { 2 - 7 } & Liberal Democrat & 14 & 3,3095 &, 47527 & \\
\cline { 2 - 7 } & 135 & 2,5519 &, 70195 & \\
\cline { 2 - 5 } & 392 & 2,6901 &, 90683 & \\
\hline
\end{tabular}

As there as a significant difference between participants' political views and the threat felt for faith tourism, Tukey Post Hoc test was conducted to find out which political views differed from one another. As seen in Table 15, those who described themselves as nationalist/conservative significantly differed from those who described themselves as a social democrat $(p>, 001)$, from those who described themselves as socialist $(\mathrm{p}>, 001)$ and from those who described themselves as "other" $(p>, 001)$. Nationalist/conservative people had the highest level of threat felt for faith tourism.

Table 15. Tukey post-hoc test

\begin{tabular}{|c|c|c|c|}
\hline Political view & Political view & $\begin{array}{c}\text { Mean } \\
\text { Difference } \\
\text { (I-J) }\end{array}$ & $\mathbf{P}$ \\
\hline \multirow{5}{*}{$\begin{array}{l}\text { Religionist/ } \\
\text { conservative }\end{array}$} & $\begin{array}{l}\text { Nationalist/ } \\
\text { conservative }\end{array}$ &,- 23407 &, 723 \\
\hline & Social democrat & ,38482 &, 188 \\
\hline & Socialist & ,52621 &, 117 \\
\hline & Liberal Democrat &,- 45536 &, 539 \\
\hline & Other & ,30231 & ,382 \\
\hline \multirow{5}{*}{$\begin{array}{l}\text { Nationalist/ } \\
\text { conservative }\end{array}$} & $\begin{array}{l}\text { Religionist/ } \\
\text { conservative }\end{array}$ &, 23407 &, 723 \\
\hline & Social democrat & ,61889 & ,001 \\
\hline & Socialist & ,76028 & ,001 \\
\hline & Liberal Democrat &,- 22129 & ,950 \\
\hline & Other & ,53638 &, 000 \\
\hline \multirow{5}{*}{ Social democrat } & $\begin{array}{l}\text { Religionist/ } \\
\text { conservative }\end{array}$ &,- 38482 &, 188 \\
\hline & $\begin{array}{l}\text { Nationalist/ } \\
\text { conservative }\end{array}$ &,- 61889 &, 000 \\
\hline & Socialist & ,14139 & ,971 \\
\hline & Liberal Democrat &,- 84018 & ,011 \\
\hline & Other &,- 08250 & ,983 \\
\hline \multirow{5}{*}{ Socialist } & $\begin{array}{l}\text { Religionist/ } \\
\text { conservative }\end{array}$ &,- 52621 &, 117 \\
\hline & \begin{tabular}{|l} 
Nationalist/ \\
conservative
\end{tabular} &,- 76028 & ,001 \\
\hline & Social democrat &,- 14139 & ,971 \\
\hline & Liberal Democrat &,- 98157 &, 007 \\
\hline & Other &,- 22389 & ,788 \\
\hline \multirow{5}{*}{ Liberal Democrat } & $\begin{array}{l}\text { Religionist/ } \\
\text { conservative }\end{array}$ & ,45536 & ,539 \\
\hline & $\begin{array}{l}\text { Nationalist/ } \\
\text { conservative }\end{array}$ & ,22129 & ,950 \\
\hline & Social democrat & ,84018 & ,011 \\
\hline & Socialist & ,98157 & ,007 \\
\hline & Other & ,75767 & ,024 \\
\hline \multirow{5}{*}{ Other } & $\begin{array}{l}\text { Religionist/ } \\
\text { conservative }\end{array}$ &,- 30231 & ,382 \\
\hline & $\begin{array}{l}\text { Nationalist/ } \\
\text { conservative }\end{array}$ &,- 53638 & ,000 \\
\hline & Social democrat & ,08250 & ,983 \\
\hline & Socialist & ,22389 &, 788 \\
\hline & Liberal Democrat &,- 75767 &, 024 \\
\hline
\end{tabular}




\section{H2: People in Eskişehir consider faith tourism as an opportunity}

As seen in Table 16, The One Sample T-test conducted on the data to see if the people in Eskişehir perceive faith tourism as an opportunity or not revealed that the average score significantly differed from the test value $3((\mathrm{p}>, 001)$. Therefore, the $\mathrm{H} 2$ was accepted.

Table 16. One sample t-test

\begin{tabular}{|l|c|c|c|c|c|}
\hline Test value $=\mathbf{3}$ \\
\hline \multirow{2}{*}{ Opportunity } & $\mathbf{N}$ & Mean & SD & t & P \\
\cline { 2 - 6 } & 392 & 3,4495 &, 83657 & 10,638 &, 001 \\
\hline
\end{tabular}

Variance analysis was also conducted on the data to see if the findings of One Sample T-test differed depending on various demographic details about the participants.

H2a: There is no relationship between gender and considering faith tourism as an opportunity

As seen in Table 17, no significant difference was found between participants' gender and their levels of opportunity felt for faith tourism in Eskişehir $(\mathrm{p}>, 239)$. Therefore, it could be suggested that the level of opportunity felt by both men and women in Eskişehir are equal. In line with this finding, it could be suggested that H1a was accepted.

Table 17. Independent samples t-test

\begin{tabular}{|l|l|c|c|c|c|c|}
\hline & Gender & $\mathbf{N}$ & Mean & Sd & t & p \\
\hline \multirow{2}{*}{ Opportunity y } & Male & 128 & 3,3906 &, 89191 &,- 970 &, 239 \\
\cline { 2 - 7 } & Female & 264 & 3,4780 &, 80859 &,- 938 & \\
\hline
\end{tabular}

H2b: There is no relationship between age and considering faith tourism as an opportunity

As seen in Table 18, One Way ANOVA test was conducted to see if there was a significant relationship between the opportunity felt for faith tourism and age. It was found that there was a significant relationship between the age and the level of opportunity felt for faith tourism in Eskişehir ( $p>, 001)$. Therefore, H1b was refused.

Table 18. One-way ANOVA test

\begin{tabular}{|l|l|l|l|l|c|}
\hline & & N & Mean & Sd & P \\
\hline \multirow{5}{*}{ Opportunity } & $15-24$ & 114 & 2,9053 &, 94268 &, 000 \\
\cline { 2 - 6 } & $25-34$ & 95 & 3,6863 &, 50919 & \\
\cline { 2 - 6 } & $35-44$ & 108 & 3,7167 &, 67761 & \\
\cline { 2 - 6 } & $45-54$ & 61 & 3,6787 &, 85812 & \\
\cline { 2 - 6 } & 55 and above & 14 & 3,2143 &, 60492 & \\
\cline { 2 - 6 } & Total & 392 & 3,4495 &, 83657 & \\
\hline
\end{tabular}

As a significant difference was found, the Tukey Post Hoc Test was conducted to see which age groups differed from one another. As seen in Table 19, it was found that there was a significant difference between those aged between 15-24 and 25-34 (( $\mathrm{p}>, 001), 35-44(\mathrm{p}>, 001), 45-54(\mathrm{p}>, 001)$. In line with this finding that it could be suggested that those aged between 15-24 had the lowest level of opportunity felt for faith tourism. As age increases, people become more aware that faith tourism is an opportunity for the city.

Table 19. Tukey post-hoc test

\begin{tabular}{|c|c|c|c|}
\hline Age & & $\begin{array}{c}\text { Mean } \\
\text { Difference }\end{array}$ & $\mathbf{P}$ \\
\hline \multirow{4}{*}{$15-24$} & $25-34$ &,- 78105 & ,000 \\
\hline & $35-44$ &,- 81140 & ,000 \\
\hline & $45-54$ &,- 77343 &, 000 \\
\hline & 55 and above &,- 30902 & ,603 \\
\hline \multirow{4}{*}{$25-34$} & $15-24$ & ,78105 &, 000 \\
\hline & $35-44$ &,- 03035 & ,999 \\
\hline & $45-54$ & ,00763 & 1,000 \\
\hline & 55 and above & ,47203 & ,192 \\
\hline \multirow{4}{*}{$35-44$} & $15-24$ & ,81140 & ,000 \\
\hline & $25-34$ & ,03035 & ,999 \\
\hline & $45-54$ & ,03798 & ,998 \\
\hline & 55 and above & ,50238 & , 137 \\
\hline \multirow{4}{*}{$45-54$} & $15-24$ & ,77343 & ,000 \\
\hline & $25-34$ &,- 00763 & 1,000 \\
\hline & $35-44$ &,- 03798 & ,998 \\
\hline & 55 and above & ,46440 & 237 \\
\hline \multirow{4}{*}{55 and above } & $15-24$ & ,30902 & ,603 \\
\hline & $25-34$ &,- 47203 & ,192 \\
\hline & $35-44$ &,- 50238 & ,137 \\
\hline & $45-54$ &,- 46440 & ,237 \\
\hline
\end{tabular}

H2c: There is no relationship between marital status and considering faith tourism as an opportunity

As seen in Table 20, Independent Samples t-test was conducted and it was found that there was a significant difference between marital status and the level of opportunity felt for faith tourism in Eskişehir ( $p>, 001)$. Therefore, H2c was refused. In line with this finding, it could be suggested that married people have more sense of opportunity for faith tourism than single people in Eskişehir.

Table 20. Independent sample t-test

\begin{tabular}{|l|l|l|l|l|l|}
\hline & Marital status & $\mathbf{N}$ & Mean & Sd & P \\
\hline \multirow{2}{*}{ Opportunity } & Married & 237 & 3,6920 &, 63684 &, 001 \\
\cline { 2 - 6 } & Single & 155 & 3,0787 &, 96254 & \\
\hline
\end{tabular}


H2d: There is no relationship between education level and considering faith tourism as an opportunity

As seen in Table 21, One Way ANOVA test was conducted to see if there was any significant difference between the level of opportunity felt for faith tourism and education level, it was found that there was not any significant difference $(p>, 078)$. Therefore, Hypothesis H2d was accepted.

Table 21. One-way ANOVA test

\begin{tabular}{|l|l|r|c|c|c|}
\hline & & N & Mean & SD & P \\
\hline \multirow{5}{*}{ Opportunity } & Primary School & 22 & 3,4182 &, 76072 &, 078 \\
\cline { 2 - 6 } & $\begin{array}{l}\text { Secondary/high } \\
\text { school }\end{array}$ & 160 & 3,4737 &, 77691 & \\
\cline { 2 - 6 } & University & 190 & 3,3863 &, 90526 & \\
\cline { 2 - 6 } & Postgraduate & 20 & 3,8900 &, 55621 & \\
\cline { 2 - 4 } & Total & 392 & 3,4495 &, 83657 & \\
\hline
\end{tabular}

H2e: There is no relationship between the political view and considering faith tourism as an opportunity

As seen in Table 22, One-way ANOVA test was conducted and it was found that there was a significant difference between political views of the people and the level of opportunity felt for faith tourism ( $p>, 001)$. Therefore, H2e was refused.

Table 22. One-way ANOVA test

\begin{tabular}{|c|c|c|c|c|c|}
\hline & & $\mathbf{N}$ & Mean & SD & $\mathbf{P}$ \\
\hline \multirow{7}{*}{ Opportunity } & $\begin{array}{l}\text { Religionist/ } \\
\text { conservative }\end{array}$ & 40 & 3,2700 & ,70827 & ,001 \\
\hline & $\begin{array}{l}\text { Nationalist/ } \\
\text { conservative }\end{array}$ & 85 & 3,7200 & ,63486 & \\
\hline & Social democrat & 87 & 3,8552 & ,58404 & \\
\hline & Socialist & 31 & 3,4000 & 1,20996 & \\
\hline & Liberal Democrat & 14 & 3,2143 & 62494 & \\
\hline & Other & 135 & 3,1067 & ,87819 & \\
\hline & Total & 392 & 3,4495 & ,83657 & \\
\hline
\end{tabular}

As there as a significant difference between participants' political views and the opportunity felt for faith tourism, Tukey Post Hoc Test was conducted to find out what political views differed from one another. As seen in Table 23, those who described themselves as religionist/conservative significantly differed from those describing themselves as nationalist/conservative $(p>033)$ and from those describing themselves as a social democrat ( $p>, 001)$. Those describing themselves as nationalist/conservative also significantly differed from those describing themselves as "other" $(p>, 001)$. Social democrats were also found to significantly differ from those who described themselves as "other" ( $p>, 001)$.

Table 23. Tukey post-hoc test

\begin{tabular}{|c|c|c|c|}
\hline Political view & Political view & $\begin{array}{c}\text { Mean } \\
\text { Difference }\end{array}$ & $\mathbf{P}$ \\
\hline \multirow{5}{*}{$\begin{array}{l}\text { Religionist/conse } \\
\text { rvative }\end{array}$} & $\begin{array}{l}\text { Nationalist/ } \\
\text { conservative }\end{array}$ &,- 45000 & ,033 \\
\hline & Social democrat &,- 58517 &, 001 \\
\hline & Socialist &,- 13000 & ,982 \\
\hline & Liberal Democrat & ,05571 & 1,000 \\
\hline & Other & ,16333 & ,854 \\
\hline \multirow{5}{*}{$\begin{array}{l}\text { Nationalist/conse } \\
\text { rvative }\end{array}$} & $\begin{array}{l}\text { Religionist/ } \\
\text { conservative }\end{array}$ & ,45000 & ,033 \\
\hline & Social democrat &,- 13517 & ,866 \\
\hline & Socialist & ,32000 & ,371 \\
\hline & Liberal Democrat & ,50571 & ,219 \\
\hline & Other & ,61333 &, 000 \\
\hline \multirow{5}{*}{ Social democrat } & $\begin{array}{l}\text { Religionist/ } \\
\text { conservative }\end{array}$ &, 58517 & ,001 \\
\hline & $\begin{array}{l}\text { Nationalist/ } \\
\text { conservative }\end{array}$ & ,13517 &, 866 \\
\hline & Socialist & ,45517 & ,061 \\
\hline & Liberal Democrat & ,64089 & ,052 \\
\hline & Other & ,74851 &, 000 \\
\hline \multirow{5}{*}{ Socialist } & $\begin{array}{l}\text { Religionist/ } \\
\text { conservative }\end{array}$ & ,13000 & ,982 \\
\hline & $\begin{array}{l}\text { Nationalist/ } \\
\text { conservative }\end{array}$ &,- 32000 & ,371 \\
\hline & Social democrat &,- 45517 & ,061 \\
\hline & Liberal Democrat & ,18571 & ,977 \\
\hline & Other & ,29333 & ,412 \\
\hline \multirow{5}{*}{$\begin{array}{l}\text { Liberal } \\
\text { Democrat }\end{array}$} & $\begin{array}{l}\text { Religionist/ } \\
\text { conservative }\end{array}$ &,- 05571 & 1,000 \\
\hline & $\begin{array}{l}\text { Nationalist/ } \\
\text { conservative }\end{array}$ &,- 50571 & ,219 \\
\hline & Social democrat &,- 64089 &, 052 \\
\hline & Socialist &,- 18571 & ,977 \\
\hline & Other & ,10762 & (996 \\
\hline \multirow{5}{*}{ Other } & $\begin{array}{l}\text { Religionist/ } \\
\text { conservative }\end{array}$ &,- 16333 & ,854 \\
\hline & \begin{tabular}{|l} 
Nationalist/ \\
conservative
\end{tabular} &,- 61333 & , 000 \\
\hline & Social democrat &,- 74851 & , 000 \\
\hline & Socialist &,- 29333 & ,412 \\
\hline & Liberal Democrat &,- 10762 & ,996 \\
\hline
\end{tabular}

\section{DISCUSSION AND CONCLUSION}

Eskişehir has gained much popularity as a touristic destination in recent years thanks to the promotions, investments and geographical location of the city in Turkey. However, there is still a need for diversification of the touristic products in the 
city as touristic activities are mostly concentrated in the city center. Eskişehir has a big potential for faith tourism with its old mosques, churches, museums and tombs.

It is believed that faith tourism will contribute to the city economy and help to diversify touristic products and to extend tourism activities across the province. For this purpose, more importance could be given to the inventory analysis for faith tourism and the renovation of old churches and mosques etc. which could have a potential for faith tourism. The finding of this study reveals that the people in Eskişehir do not feel any threat for faith tourism in general, but when the demographic information was considered in the analysis, it was found that those aged between 45-54 significantly had higher threat felt for faith tourism. It could be suggested that as age increases, the level of threat felt also increases. Marital status was also found not to be a factor in the level of threat for faith tourism as both married and single people have an equal level of threat for faith tourism. When the education level of the participants was considered, those who are graduates of primary school had a lower level of threat felt for faith tourism. Those with a postgraduate degree have the lowest level of threat felt for faith tourism. The fact that the literacy level of the city is high could be used as an advantage and facilitating factor in the promotion of faith tourism in the city by the local governors.

The data of the study were also examined considering the participants' political views, and it was found that those who described themselves as nationalist/conservative had the highest level of threat felt for faith tourism compared to the level of those describing themselves as social democrat and other (those with a political view except the ones given in the study. Here, the fact that the nationalist/conservative people had a higher level of threat for faith tourism than those religionist/conservative people is attention taking. Another attention taking point is that the rate of those describing themselves under the heading of "other" is very high in spite of the fact that major political views were provided on the questionnaire. It is thought that people highly avoid sharing their political views with the public.

When the factor of opportunity was considered, it was found that the people in Eskişehir consider faith tourism as an opportunity in general. This finding is valuable as the positive attitudes of local people are very important in the achievement of faith tourism in a local destination. In other words, the people in Eskişehir are ready for faith tourism projects. When demographic information regarding the participants was considered, it was found that both men and women in the city equally consider faith tourism as an opportunity. However, the age range was found to be a factor in sensing faith tourism as an opportunity because those aged between 15-24 were found to have the lowest sense of opportunity for faith tourism in the city. This could be used to make a generalization that young people need more awareness raising about faith tourism and its economic and social contributions. When participants' marital status was considered, married people were found to have a higher sense of opportunity for faith tourism than single people. When the education levels of the participants were considered, it was found that education was not a factor in perceiving faith tourism as an opportunity. However, it was found that political views of the participants were found to be a factor in considering faith tourism as an opportunity because those who described themselves as religionist/conservative had a lower level of the sense of opportunity for faith tourism than those describing themselves as nationalist/conservative, social democrat and other. It was also found that those describing themselves as "other" was also found to have a lower sense of opportunity for faith tourism than those describing themselves as nationalist/conservative. Here it is attention taking to see that religionist and conservative people did not see faith, religion-based tourism as a value which could have a contribution to the local economy.

As seen from findings of this study, faith tourism in Eskişehir is suggested to be an issue to be considered by the local governors as it could offer new opportunities for touristic development in the city and for the diversification of tourism products offered to visitors and for the spread of tourism activities across the province. Thus more people across the province can earn their lives in tourism activities. Faith tourism can also be used in triggering the rural development in the countryside by opening the structures with a value for faith tourism in the countryside. Thus the life in the countryside can also be supported with the promotion of faith tourism. 


\section{REFERENCES}

Akat, Ö. (2000): Pazarlama Ağırlıklı Turizm İşletmeciliği, İstanbul: Ekin Kitabevi.

Angeles, R. G., \& Javier, D. E. C. (2008). Religious events as special interest tourism. A Spanish experience. PASOS. Revista de Turismo y Patrimonio Cultural, 6(3), 419-433.

Cohen, L., Manion, L. and Morrison, K. (2000). Action research. Research methods in education, 5, 226-244.

Cortina, J. M. (1993). What is coefficient alpha? An examination of theory and applications. Journal of Applied Psychology, 78(1), 98-104. doi:10.1037/0021-9010.78.1.98.

Gan, Z., Ma, Y., \& Song, B. (2000). Tourism Resource of Religious Culture. Tourism Resource and Development, 157-176.

EBB (2019). Eskişehir'in Turizm Mucizesi. Retrieved from

http://www.eskisehir.bel.tr/icerik dvm.php?icerik $\mathrm{id}=1730 \&$ cat icerik=1\&menu id=24 Access Date: 12 January 2019

EOSB (2019). Eskişehir'in Coğrafi Konumu. Retrieved from http://www.eosb.org.tr/ sosyal gostergeler/ Access Date: 15 January 2019 Erbaş,A. (2002), İslam Dışı Dinlerde Hac. Sakarya Üniversitesi İlahiyat Fakültesi Dergisi, 5

Hacioğlu, N. (2000). Turizm Pazarlamass (4. baskı). Uludağ Üniversitesi Güçlendirme Vakfı, Press Number:160, Vipaş A.Ş, Bursa.

Hair, J.F. Jr., Anderson, R.E., Tatham, R.L., and Black, W.C. (1998). Multivariate Data Analysis, (5th Edition). Upper Saddle River, NJ: Prentice Hall.

Egresi, I., Bayram, B., Kara, F., \& Kesik, O. A. (2012). Unlocking the potential of religious tourism in Turkey. GeoJournal of Tourism and Geosites, 9(1), 17-23.

Jennings, G. (2001). Tourism research. Australia: John Wiley \&Son

Karaman, S. and Usta, K. (2006). İnanç Turizmi Açısından İznik ve Bir Uygulama Çalışması. III. Balıkesir Ulusal Turizm Kongresi, Balıkesir, ss:473-489.

Kozak, M.A.-Kozak, N.-Kozak, M. (2010). Genel Turizm: Ilkeler-Kavramlar. Detay Yayınları
McKelvie, J. (2005). Religious tourism. Travel \& Tourism Analyst, (4), 1-47.

Nufusu.com (2019). Eskişehir Nüfusu. Retrieved from https://www.nufusu.com/il/eskisehir-nufusu Access Date: 10 January 2019

Rodriques S.A.M (2012) Motivations, Experiences and Potential Impacts of Visitors to a Monastery in New Zealand: A Case Study. The University of Waikato Department of Tourism and Hospitality Management, New Zealand.

Rojo, D. M. (2007). Religious tourism: the way to Santiago. MA European Tourism Management, Bournemouth University.

Sargın, S. (2006). Yalvaç'ta İnanç Turizmi. Fırat Üniversitesi Sosyal Bilimler Dergisi.16, 2, pp. 118.

Seçilmiş, C. (2011). Ziyaretçilerin gözüyle Eskişehir turizminin gelişmesini etkileyen sorunlar. Işsletme Araştırmaları Dergisi, 3(3), 3757.

Şahin, F. (2012). Eskiş̧ehir ilinin kültür turizmi potansiyeli: Mevcut durum ve öneriler. TC Kültür ve Turizm Bakanlığı Eskişehir Kültür Varlıklarını Koruma Bölge Kurulu Müdürlüğü, Uzmanlık Tezi, Eskişehir.

Şahiner, T. (2012). İnanç turizmi potansiyeli ve halkın inanç turizmine bakışı açısından Karaman (Master's thesis, Karamanoğlu Mehmetbey Üniversitesi Sosyal Bilimler Enstitüsü).

Schmitt, N. (1996). Uses and abuses of coefficient alpha. Psychological Assessment,8(4), 350-353. doi:10.1037 /1040-3590.8.4.350.

Timothy, D. J., \& Olsen, D. H. (2006). Tourism and religious journeys. In tourism, religion and spiritual journeys (pp. 17-38). Routledge.

Tunç, A., Saç, F. (1998). Genel Turizm GelişimiGeleceği. Detay Yayıncılık, Ankara

Usta, K. M. (2005). İnanç Turizmi Potansiyeli Açısından İznik'in Değerlendirilmesi, Balıkesir Üniversitesi Sosyal Bilimler Enstitüsü Turizm İşletmeciliği ve Otelcilik Anabilim Dalı Yüksek Lisans Tezi, Balıkesir.

Vidic, N. (2007). Religious tourism as postmodern tourism on the territory of Fruska Gora. University of Craiova, Geography Series, 10 (new series), 187-205. 
Retrieved from http://analegeo.ro/wpcontent/uploads/2010/07/Articolul-18-NadaVidic.pdf, Access Date: 27 January 2019

Vorzsak, M., \& Gut, C. M. (2009). A strategic prognosis of religious tourism in Romania: Proceedings of the 2nd International Conference on Cultural Heritage and Tourism, 29-34. Rhodos: WSEAS Press. Retrieved from http://www.wseas.us/e-library/ conferences/2009/ rodos/CUHT/CUHT03.pdf, Access Date: 7 January 2019

Yandell, K. E. (2002). Philosophy of Religion: A Contemporary Introduction. Routledge Contemporary Introductions to Philosophy. London: Routledge.
Wright K. (2007). Religious Tourism, A New Era, A Dynamic Industry. Retrieved from http://www.tourismreview.com/fm703/religioustourism-a-new-era-adynamic-industry.pdf/, Access Date: 10 January 2019

World Tourism Organization. (2011). Religious Tourism in Asia and the Pacific. Madrid, Spain: World Tourism Organization.

Zengin, A. (2010). Eyüp Kentsel Sit Alanının İnanç Turizmi Kapsamında Değerlendirilmesi ve Yerleşim Dokusunun Korunması Üzerine Bir Araştırma. Mimar Sinan Fine Arts University, Institute of Science, Department of Architecture, Unpublished MA Thesis. Istanbul. 